\title{
Pengembangan Efikasi Diri Siswa SMK dalam Menentukan Keputusan Karir Melalui Layanan Bimbingan Kelompok
}

\author{
Rois Nafi'ul Umam \\ Universitas Islam Negeri (UIN) Sunan Kalijaga \\ 20200011107@student.uin-suka.ac.id
}

\begin{abstract}
A career as a process that individuals will undertake in the future, needs to be carefully prepared since they are at the SMA / SMK education level. Through careful career planning, students can easily make the right decisions about their careers. As for the obstacles that occur, students cannot make their own career decisions which are caused by low self-efficacy/self-confidence. The purpose of this study is to explain the role of group counseling services in developing student self-efficacy in achieving career decisions. This type of research is field research with a qualitative approach and a descriptive-analytical method. Data collection techniques were carried out by observation and interviews. Symptoms of low selfefficacy experienced by students are 1) difficulty to make career decisions, 2) not confident in their career plans, 3) worry that they are not absorbed in the world of work. Group guidance services are carried out in 4 stages, namely the initial stage, the transition stage, the activity stage, and the final stage. The results of the counseling service show that students have good self-efficacy, can make career decisions, are confident, and do not experience worries about their career plans.
\end{abstract}

Keywords: Self-efficacy; Vocational Student; Career Decisions; Group Counseling

\begin{abstract}
Abstrak
Karir sebagai sebuah proses yang akan dijalani individu di masa yang akan datang, perlu untuk dipersiapkan dengan matang sejak berada pada jenjang pendidikan SMA/SMK. Melalui perencanaan karir yang matang, siswa dengan mudah dapat mengambil keputusan yang tepat mengenai karir yang akan dijalaninya. Adapun hambatan
\end{abstract}


yang terjadi adalah siswa tidak dapat membuat keputusan karirnya sendiri yang diakibatkan oleh rendahnya efikasi diri/kepercayaan diri. Tujuan dalam penelitian ini adalah menjelaskan peran dari layanan bimbingan kelompok dalam mengembangkan efikasi diri siswa dalam mencapai keputusan karir. Jenis penelitian ini adalah penelitian lapangan dengan pendekatan kualitatif dan metode deskriptif analitis. Teknik pengumpulan data dilakukan dengan observasi dan wawancara. Gejala efikasi diri rendah yang dialami oleh para siswa adalah 1) sulit menentukan keputusan karir, 2) tidak percaya diri dengan rencana karirnya, 3) kekhawatiran tidak terserap dalam dunia kerja. Layanan bimbingan kelompok dilakukan melalui 4 tahap yaitu tahap awal, tahap transisi, tahap kegiatan dan tahap akhir. Hasil dari layanan bimbingan konseling menunjukkan siswa memiliki efikasi diri yang baik, dapat membuat keputusan karir, percaya diri dan tidak mengalami kekhawatiran tentang rencana karirnya

Kata Kunci: Efikasi Diri; Siswa SMK; Keputusan Karir; Bimbingan Kelompok

\section{Pendahuluan}

Karir merupakan sikap dan perilaku yang berhubungan dengan pengalaman dan kegiatan kerja sepanjang hidup dari individu tersebut. ${ }^{1}$ Karir berhubungan dengan rencana dan pekerjaan yang akan diambil oleh setiap individu. Karir yang dimiliki individu menunjukkan perkembangan kinerja selama ini selama ia berada dalam sebuah organisasi/perusahaan. Adapun menurut Sukardi, karir merupakan rangkaian pekerjaan, jabatan dan kedudukan yang berpengaruh dalam dunia kerja. ${ }^{2}$ Melalui karir yang baik, individu akan memperoleh harapan untuk terus berkembang dan menjadi lebih maju. ${ }^{3}$ Dari beberapa definisi diatas, dapat disimpulkan bahwa karir merupakan rencana dalam hal pekerjaan, jabatan dan kedudukan yang akan diperoleh individu melalui usaha dan kerja kerasnya untuk mencapai kemajuan dalam hidupnya.

Karir individu di masa depan hendaknya harus dipersiapkan sejak ia berada pada tingkat satuan pendidikan, baik mulai tingkat sekolah dasar hingga ke perguruan tinggi. Hal ini dikarenakan perencanaan perlu disiapkan secara baik

${ }^{1}$ Rahmawaty Anita, "Harmoni Dalam Keluarga Perempuan Karir : Upaya Mewujudkan Kesetaraan Dan Keadilan Gender Dalam Keluarga,” Palastren 8, no. 1 (2015): 1-34.

${ }^{2}$ H.R. Partino, "Kematangan Karir Siswa SMA," Psikologika: Jurnal Pemikiran dan Penelitian Psikologi 11, no. 21 (2006): 103-108.

${ }^{3}$ Nurmasari, "Peranan Penting Perencanaan Dan Pengembangan Karier," PUBLIKa.,Vol.1,No.2,Oktober,hal 268-281 (2015) 1, no. 2 (2015): 268-281, https://docs.google.com/viewerng/viewer?url=http://jurnal.uir.ac.id/index.php/PUB/article/ download/917/612. 
dan pada masa tersebut individu dalam proses belajar dan mengenal kemampuan diri sehingga dapat mengambil keputusan yang baik untuk karirnya kedepan. ${ }^{4}$ Secara umum individu dapat memulai perencanaan karir ketika ia berada pada jenjang pendidikan menengah atas/kejuruan. Hal ini dikarenakan pada masa tersebut siswa dapat memilih jenis sekolah berdasarkan minat dan bakatnya, baik yang mengarah pada kemampuan akademis seperti Sekolah Menengah Atas (SMA) maupun yang mengarah pada kemampuan vokasional seperti Sekolah Menengah Kejuruan (SMK). ${ }^{5}$ Siswa yang memilih untuk bersekolah di satuan pendidikan SMK pada dasarnya ingin berfokus untuk mengembangkan diri melalui berbagai keterampilan yang ada sehingga dapat bekerja sesuai dengan minat dan keterampilan yang dimilikinya. ${ }^{6}$ Keterampilan yang diajarkan dalam satuan pendidikan SMK relatif beragama, seperti bidang teknologi informasi, teknik dan rekayasa sosial, bisnis dan manajemen, kesehatan dan pekerjaan sosial, pariwisata dan lain sebagainya. Melalui berbagai bidang keterampilan tersebut, diharapkan setelah lulus nanti, siswa dapat melanjutkan pendidikannya sesuai dengan keterampilannya tersebut atau dapat langsung mengaplikasikan kemampuan yang dimilikinya tersebut.

Akan tetapi tidak semua siswa SMK dapat membuat perencanaan karir yang baik dan matang. Hal ini dikarenakan rasa bimbang dan kurang percaya diri dalam memilih rencana karirnya, baik untuk melanjutkan pendidikan ataupun bekerja. ${ }^{8}$ Masalah lain yang kemudian muncul adalah rendahnya efikasi diri yang dimiliki oleh siswa tersebut berhubungan dengan karirnya. Menurut Bandura, efikasi diri sebagai sebuah keyakinan tentang seberapa besar usaha yang dilakukan individu dalam situasi dan kondisi tertentu." Ditambahkannya, bahwasanya efikasi diri juga menunjukkan seberapa bertahannya individu dalam menghadapi kesulitan dan bagaimana tingkat kesulitan/kemudahan kemudian mempengaruhi perilaku individu di masa yang akan datang. Pendapat dari Bandura ini didukung oleh pendapat lain yang dikemukakan oleh Kreitner dan Kinicki yang menyatakan bahwa efikasi diri merupakan bentuk optimisme atau

${ }^{4}$ Hermi Pasmawati, "Urgensi Bimbingan Karier Di Perguruan Tinggi Untuk Membantu Kesiapan Mahasiwa Tahun Akhir Memasuki Dunia Kerja," Jurnal Ilmiah Syi'ar 18, no. 1 (2018): 1.

${ }^{5}$ Deasy Yunika Khairun, Melly Sri Sulastri, and Anne Hafina, "Layanan Bimbingan

Karir Dalam Peningkatan Kematangan Eksplorasi Karir Siswa," Jurnal Penelitian Bimbingan Konseling 1, no. 1 (2016): 1-23.

'Imam A. Alimudin, Tatang Permana, and Sriyono Sriyono, "Studi Kesiapan Kerja

Peserta Didik Smk Untuk Bekerja Di Industri Perbaikan Bodi Otomotif," Journal of Mechanical Engineering Education 5, no. 2 (2019): 191.

${ }^{7}$ Ika Zenita Ratnaningsih et al., "Kematangan Karier Siswa SMK Ditinjau Dari Jenis Kelamin Dan Jurusan," Jurnal Humanitas 13, no. 2 (2016): 113-119.

${ }^{8}$ Nofianti Eka Permadi, "Masalah-Masalah Yang Dihadapi Peserta Didik Dalam Perencanaan Karir Dan Implikasinya Terhadap Pelayanan Bimbingan Karir," Jurnal Penelitian Bimbingan dan Konseling 1 (2016): 134-145.

${ }^{9}$ Rizal Rusdyanto, "Hubungan Antara Tingkat Self-Efficacy Dengan Tingkat Kinerja Guru Di Sekolah Dasar Irada Gresik,” Jurnal Psikosains 10, no. 1 (2015): 67-78. 
keyakinan dalam diri individu perihal peluang dalam mencapai keberhasilan sebuah tugas yang diberikan. ${ }^{10}$ Efikasi diri yang dimiliki oleh setiap individu, berada pada level yang berbeda-beda, ada individu yang memiliki level efikasi diri yang tinggi dan ada individu yang memiliki efikasi diri rendah. Tingkat efikasi diri individu dipengaruhi oleh berbagai faktor, seperti tingkat kesulitan tugas, dukungan dari pihak luar dalam bentuk reward dan punishment serta banyaknya informasi yang diperoleh individu perihal efikasi diri yang dimilikinya. Untuk dapat mengembangkan efikasi diri, maka, sumber efikasi diri seperti prestasi, pengalaman dari orang lain, serta pendekatan secara persuasi menjadi hal yang penting keberadaannya untuk mendorong hal tersebut. ${ }^{11}$

Dalam kondisi yang ideal, efikasi dalam diri individu secara umum berada pada tingkat sedang hingga tingkat yang tinggi. Individu yang memiliki efikasi diri tinggi memiliki beberapa ciri yang diantaranya memiliki kepercayaan diri yang baik, memiliki keyakinan diri untuk dapat mengatasi masalah serta memiliki tujuan dan komitmen yang kuat untuk menyelesaikan tugasnya. ${ }^{12}$ Permasalahan muncul ketika efikasi diri individu berada dalam kondisi yang rendah. Efikasi diri rendah pada individu ditandai dengan beberapa ciri seperti lamban ragu pada kemampuan diri, cenderung cepat menyerah, serta tidak memiliki keyakinan dapat mengatasi rintangan yang dihadapi. Dalam konteks siswa yang sedang merencanakan keputusan karir, efikasi diri rendah merupakan salah satu penghambat bagi siswa untuk dapat menetapkan keputusan karir yang akan diambil. Efikasi diri rendah yang dialami siswa dalam membuat keputusan karir diantaranya lamban dalam mempersiapkan karir, takut akan kegagalan dalam membuat keputusan yang penting akan karirnya, serta ragu pada diri sendiri untuk dapat membuat keputusan yang baik dan matang perihal karirnya. Permasalahan ini menjadi hal yang penting untuk ditangani, agar para siswa tersebut tidak terus berada dalam kondisi efikasi diri yang rendah serta dapat mengambil keputusan yang cepat dan tepat mengenai karirnya di masa yang akan datang. ${ }^{13}$ Untuk membantu siswa dalam mengatasi permasalahan tersebut, maka dapat ditangani melalui layanan bimbingan konseling di sekolah dengan kegiatan berbasis kelompok seperti bimbingan kelompok

${ }^{10}$ I Made Rustika, "Efikasi Diri: Tinjauan Teori Albert Bandura," Buletin Psikologi 20, no. 1 (2016): 18-25.

${ }^{11}$ Hara Permana, Farida Harahap, and Budi Astuti, "Hubungan Antara Efikasi Diri Dengan Kecemasan Dalam Menghadapi Ujian Pada Siswa Kelas Ix Di Mts Al Hikmah Brebes," Hisbah: Jurnal Bimbingan Konseling dan Dakwah Islam 13, no. 2 (2017): 51-68.

12 Arya Firmanu Jendra and Sugiyo Sugiyo, "Pengaruh Efikasi Diri Terhadap Kecemasan Presentasi Siswa Kelas XI Di SMA Negeri 1 Wuryantoro," KONSELING EDUKASI "Journal of Guidance and Counseling” 4, no. 1 (2020): 138-159.

13 Lorensia Claudia Charista, Yari Dwi Kurniangsih, and Tritjahyo Danny Soesilo, "Hubungan Efikasi Diri Dengan Kematangan Karir Siswa," Jurnal Penelitian dan Pengembangan Pendidikan 2, no. 1 (2018): 23-29. 
Layanan bimbingan kelompok merupakan sebuah kegiatan yang dilakukan secara berkelanjutan yang dilakukan untuk memberikan informasi dan pemahaman melalui dinamika kelompok. Pada kegiatan bimbingan kelompok tersebut, setiap anggota kelompok dapat menyampaikan ide, pendapat dan gagasannya secara bebas dan terbuka pada forum tersebut. ${ }^{14}$ Dalam pendapat lain yang dikemukakan oleh Romlah bahwa bimbingan kelompok merupakan proses pemberian bantuan atau pemberian informasi melalui berbagai media yang dimiliki oleh fasilitator untuk membantu individu dalam mencapai kematangan dalam berpikir dan dapat mengambil keputusan yang terbaik. ${ }^{15}$ Dari beberapa pendapat tersebut dapat disimpulkan bahwa bimbingan kelompok merupakan kegiatan pemberian bantuan atau informasi yang dilakukan dengan menggunakan berbagai media yang dapat dimanfaatkan dan dilakukan dengan memanfaatkan dinamika kelompok. Tujuan dari keberadaan bimbingan kelompok adalah mendorong pengembangan pemikiran, persepsi dan wawasan baru bagi individu yang diharapkan dapat membantunya dalam menentukan arah tujuan hidup yang hendak dicapai. Pada kegiatan layanan bimbingan kelompok terdapat beberapa asas yang harus dipatuhi oleh fasilitator maupun anggota kelompok, seperti asas kerahasaan, asas kesukarelaan, asas keterbukaan, asas kemandirian, asas kenormatifan dan lain sebagainya. Dalam hal layanan pengembangan efikasi diri siswa berkenaan dengan karirnya, layanan bimbingan kelompok digunakan untuk memberikan informasi-informasi karir yang dibutuhkan siswa sehingga siswa tersebut dapat mengambil keputusan yang terbaik mengenai karir yang akan dijalaninya. ${ }^{16}$

Beberapa hasil penelitian menunjukkan bahwa efikasi diri memiliki hubungan dengan kemantapan karir siswa, seperti penelitian yang dilakukan oleh Maulida yang menunjukkan bahwa efikasi diri yang dimiliki oleh individu berpengaruh terhadap kesiapan kerja siswa SMK. Jika individu memiliki efikasi diri yang tinggi, maka ia akan siap untuk bekerja, dan jika ia memiliki efikasi diri yang rendah, maka individu itu ragu dan belum siap untuk bekerja. ${ }^{17}$ Efikasi diri juga dipandang sebagai faktor yang berpengaruh terhadap pengambilan keputusan karir siswa SMK. Hal ini ditinjau dari penelitian yang dilakukan oleh

\footnotetext{
${ }^{14}$ Erwin Erlangga, "Bimbingan Kelompok Meningkatkan Keterampilan Berkomunikasi Siswa," Psympatbic: Jurnal Ilmiah Psikologi 4, no. 1 (2017): 149-156.

15 Anis Nuril Laili Sulistyowati, "Layanan Bimbingan Kelompok Untuk Meningkatka Keterampilan Belajar Siswa," Edukasia: Jurnal Penelitian Pendidikan Islam 10, no. 2 (2015): 413 430.

${ }^{16}$ Aliqol Ana and Mungin Eddy Wibowo, "Bimbingan Kelompok Dengan Teknik Role Playing Untuk Meningkatkan Self-Efficacy Dan Harapan Hasil (Outcome Expectations) Karir Siswa," Jurnal Bimbingan Konseling 6, no. 1 (2017): 49-53.

${ }^{17}$ Nuzulia Intan Maulida, Pengarub Perencanaan Karir Dan Efikasi Diri Terbadap Kesiapan Kerja Peserta Didik Di SMK Se Kabupaten Tegal (Semarang: Universitas Negeri Semarang, 2017).
} 
Frederica yang menyatakan bahwa 38,9\% siswa dalam pengambilan keputusan mengenai karirnya dipengaruhi oleh efikasi diri yang ada dalam dirinya. ${ }^{18}$

Dalam penelitian yang dilakukan oleh Herin dan Sawitri, untuk dapat mencapai kematangan karir, siswa selain memerlukan dorongan dari dalam diri individu, juga perlu adanya dorongan/dukungan dari orang tua. Dukungan orang tua berpengaruh sebesar 30\% dari kematangan karir yang akan ditempuh para siswa. Dukungan dari orang tua akan menambah kepercayaan diri siswa dalam memilih rencana karir yang akan diambil, dan apabila siswa tersebut tidak mendapat dukungan dari orang tua, maka siswa tersebut akan sulit dalam menentukan keputusan karirnya atau tidak yakin dengan rencana karir yang telah diambilnya. ${ }^{19}$ Selain dukungan dari orang tua, peran sekolah juga penting untuk membantu siswa dalam menentukan keputusan karirnya. Dari penelitian yang dilakukan oleh Isnain, dukungan pembentukan dan penentuan keputusan karir siswa dilakukan dalam bentuk pemberian informasi mengenai karir yang sangat dibutuhkan oleh siswa. Hal ini untuk mendukung eksplorasi karir siswa yang ditandai dengan pendalaman mengenai rencana karir yang akan diambil dan kemampuan mengenal minat dan potensi diri sehingga siswa dapat mengambil keputusan yang tepat dan matang terkait dengan karirnya. ${ }^{20}$

Dari hasil observasi yang dilaksanakan oleh Guru BK di SMKN 8 Penajam Paser Utara (PPU) selama bulan September-November 2019, ada 10 orang siswa kelas XII yang masih merasa bimbang dan belum dapat mengembangkan efikasi dirinya untuk dapat membuat keputusan untuk dirinya. Hal ini ditandai dengan siswa yang masih bingung untuk memilih antara bekerja dan kuliah. Jika memilih untuk kuliah, siswa tersebut masih bingung dengan program studi yang akan diambil, sedangkan siswa jika memilih untuk bekerja, mereka belum memahami profesi yang terkait dengan jurusan yang ia tekuni di SMK. Dari hal tersebut mereka perlu layanan lebih lanjut untuk mengatasi keraguan/kebingungan yang mereka rasakan untuk dapat mengembangan efikasi diri pada diri mereka sehingga dapat mengambil keputusan karir yang tepat.

Berdasarkan latar belakang diatas, penelitian ini berfokus pada pengembangan efikasi diri siswa SMK dalam mencapai kematangan karir melalui layanan bimbingan konseling. Adapun rumusan masalah dalam penelitian ini adalah; Bagaimana kondisi efikasi diri yang dialami oleh siswa SMK berkaitan dengan perencanaan karirnya? Bagaimana proseslayanan bimbingan konseling yang dilakukan dalam pengembangan efikasi diri siswa SMK untuk menetapkan

${ }^{18}$ Angela Gita Frederica, Hubungan Antara Efikasi Diri Dengan Pengambilan Keputusan Karir Pada Siswal i Sekolah Menengah Kejuruan (Smk), Skripsi, 2020.

${ }^{19}$ Mutiara Herin and Dian Ratna Sawitri, "Dukungan Orang Tua Dan Kematangan Karir Pada Siswa Smk Program Keahlian Tata Boga,” Empati 6, no. 1 (2017): 301-306.

${ }^{20}$ Mauliddian Isnain and Desi Nurwidawati, "Hubungan Antara Efikasi Diri Dengan Kematangan Karir Pada Siswa Kelas XI DI SMKN 1 Surabaya," Character: Jurnal Penelitian Psikologi 05, no. 02 (2018): 1. 
keputusan karir? Bagaimana hasil dari layanan bimbingan konseling dalam pengembangan efikasi diri siswa SMK untuk mencapai keputusan karir yang baik?

Penelitian ini merupakan penelitian lapangan (field research) yang dilaksanakan di SMKN 8 Penajam Paser Utara (PPU) dan menggunakan pendekatan kualitatif. Pendekatan kualitatif merupakan penelitian yang ditujukan untuk memahami fenomena-fenomena yang terjadi dalam hal efikasi diri siswa SMK yang rendah menjadi sebuah objek penelitian yang menarik untuk diteliti. ${ }^{21}$ Metode yang digunakan dalam penelitian ini yaitu deskriptif analitis, metode ini berfungsi untuk mendeskripsikan atau memberikan gambaran objek yang diteliti dan telah terkumpul. ${ }^{22}$ Teknik pengumpulan data yang digunakan adalah observasi dan wawancara. Observasi dilakukan untuk mengamati perilaku siswa pada saat penyampaian informasi mengenai karir yang menunjukkan siswa tersebut memiliki efikasi diri yang rendah. Adapun wawancara dilakukan untuk mengetahui masalah secara mendalam yang mereka hadapi berkaitan dengan efikasi diri mereka. Informan-informan dalam penelitian ini adalah siswa/siswi kelas XII SMKN 8 Penajam Paser Utara yang sesuai dengan kriteria yang telah ditetapkan oleh peneliti, seperti sulit menentukan pilihan antara kuliah dan bekerja, ragu dengan jurusan perkuliahan yang akan diambil, dan ragu dengan rencana pekerjaan yang akan diambil. Dari seluruh siswa kelas XII di SMKN 8 Penajam Paser Utara ada 10 orang siswa yang memiliki gejala efikasi diri rendah berhubungan dengan karirnya. Berikut akan dipaparkan identitas dari informan dalam penelitian ini:

\begin{tabular}{|c|c|c|c|c|}
\hline No & Nama (Inisial) & $\begin{array}{c}\text { Jenis } \\
\text { Kelamin }\end{array}$ & Umur & Kelas \\
\hline 1 & HR & P & 17 & XII UPW 1 \\
\hline 2 & RF & L & 17 & XII-TKJ 2 \\
\hline 3 & GL & L & 17 & XII MM 1 \\
\hline 4 & FD & L & 17 & XII MM 2 \\
\hline 5 & AL & P & 17 & XII TKJ 1 \\
\hline 6 & DN & P & 17 & XII AK 1 \\
\hline 7 & AN & L & 17 & XII TKJ 1 \\
\hline 8 & SF & L & 17 & XII MM 2 \\
\hline 9 & EN & P & 17 & XII UPW 2 \\
\hline 10 & FR & P & 17 & XII AK 1 \\
\hline
\end{tabular}

Data yang telah dikumpulkan kemudian dianalisis melalui tahapan yang diantaranya; 1) data mengenai tingkat efikasi diri karir siswa SMK yang diperoleh melalui observasi, wawancara dan dokumentasi kemudian direduksi untuk

${ }^{21}$ Yoki Yusanto, "Ragam Pendekatan Penelitian Kualitatif," Journal of Scientific Communication (Jsc) 1, no. 1 (2020): 1-13.

${ }^{22}$ Ibid. 
mencari inti permasalahan dan gejala efikasi diri rendah yang dimiliki oleh para siswa, 2) langkah berikutnya adalah dengan verifikasi data untuk mengetahui wacana layanan konseling yang tepat untuk siswa tersebut, 3) setelah melakukan reduksi dan verifikasi data, kemudian dapat ditarik kesimpulan bahwa siswa tersebut mengalami masalah efikasi diri rendah dan rencana intervensi yang akan dilakukan adalah layanan bimbingan dan konseling.

\section{Hasil dan Pembahasan}

Dari wawancara yang dilakukan oleh peneliti dengan informan yaitu beberapa siswa kelas XII SMKN 8 Penajam Paser Utara yang belum dapat menentukan keputusan karirnya, diketahui terdapat beberapa kondisi yang menjadi gambaran umum tingkat efikasi diri yang rendah pada siswa tersebut berkenaan dengan karirnya. Adapun kondisi efikasi diri rendah yang dialami oleh para siswa berkenaan dengan karirnya seperti sulit dalam menentukan keputusan karir yang akan dipilih, tidak percaya diri dengan rencana karir yang telah dipilih serta kekhawatiran tidak dapat terserap dengan baik di dunia kerja. Kondisi efikasi diri yang rendah tersebut disebabkan oleh faktor yang berasal dari dalam diri siswa maupun yang berasal dari luar diri siswa, seperti pihak sekolah maupun orang tua. Berikut adalah pemaparan detail dari kondisi efikasi diri rendah yang dialami oleh siswa dalam menentukan keputusan karimya:

\section{Kesulitan Menentukan Keputusan Karir}

Karir sebagai bagian dari masa depan yang akan dijalani harus memiliki dasar perencanaan yang baik dan matang. Hal ini dilakukan agar karir yang dijalani nantinya sesuai dengan minat dan bakat individu tersebut. ${ }^{23}$ Ketika individu menjalani karir tidak sesuai dengan minat dan bakatnya, maka ia berpotensi terhambat dalam pengembangan karirnya. Secara umum rencana karir yang dapat diambil oleh siswa SMK adalah langsung bekerja sesuai dengan keterampilan yang telah dipelajarinya. Selain itu tidak menutup kemungkinan siswa tersebut juga dapat melanjutkan ke jenjang perguruan tinggi. Akan tetapi tidak semua siswa dapat menentukan keputusan karir yang akan diambil dari berbagai alternatif perencaan karirnya. Dalam hasil wawancara yang dilakukan terhadap GL dan DN, mereka bingung dalam memilih rencana karir yang akan diambilnya.

"Saya merasa bingung memilih untuk bekerja atau kuliah, saya inginnya langsung bekerja, tetapi orang tua saya inginnya saya bisa kuliah" 24

"Saya bingung antara mau kuliah atau kerja, saya inginnya kuliah dulu, akan tetapi orang tua saya dalam kondisi yang kurang memungkinkan secara ekonomi

${ }^{23}$ Edris Zamroni, "Urgensi Career Decision Making Skills Dalam Penentuan Arah Peminatan Peserta Didik,” Jurnal Konseling Gusjigang 2, no. 2 (2016): 140-152.

${ }^{24}$ Wawancara dengan GL pada tanggal 13 Januari 2020 
sehingga diminta untuk bekerja dahulu. Akan tetapi jika saya kuliah sambil bekerja, saya khawatir kuliah saya menjadi tidak maksimal"25

Dari hasil wawanacara diatas, dapat diketahui penyebab kebimbangan siswa tersebut didominasi oleh faktor yang berasal dari luar diri mereka yaitu dukungan dari orang tua. Dukungan orang tua tersebut tidak sesuai dengan harapan dari siswa tersebut, seperti adanya keinginan yang berbeda dengan anaknya dan kurangnya dukungan secara ekonomi untuk membantu siswa tersebut mencapai tujuan yang diharapkannya. Kedua hal tersebut membuat mereka tidak dapat mengambil keputusan secara cepat dalam perencanaan karirnya.

\section{Tidak Percaya Diri dengan Rencana Karir yang Telah Dipilih}

Kepercayaan diri merupakan sikap atau keyakinan atas kemampuan diri sehingga dapat mengambil keputusan yang dilakukan secara rasional. Kepercayaan diri merupakan salah satu pendorong dalam mencapai kesuksesan karir setiap individu. Melalui kepercayaan diri tersebut individu dapat mengembangkan diri menjadi pribadi yang lebih baik. ${ }^{26}$ Dalam hal karir, kepercayaan diri juga penting untuk mencapai tujuan karir yang diharapkan. Kepercayaan diri harus dibangun sejak membuat perencanaan karir hingga dapat mencapai puncak karirnya. Informan dalam penelitian ini memiliki masalah dalam kepercayaan diri, meskipun ia telah membuat perencaan karir, sehingga ia memikirkan kembali rencana karirnya tersebut.

"Saya sebenarnya udah mau merencanakan kuliah dan jurusannya tidak sesuai dengan keterampilan yang saya pelajari selama SMK ini. Tapi saya menjadi tidak percaya diri ketika jumlah peminat jurusan itu sangat banyak dan saya tidak yak saya dapat masuk ke jurusan itu"27

"Saya juga sudah punya rencana jurusan kuliah yang akan diambil, akan tetapi teman saya menyarankan saya untuk kuliah di jurusan lain, karena menurutnya itu lebih cocok daripada yang saya pilih, jadi saya mulai tidak percaya diri dengan jurusan yang saya ambil",28

Dari hasil wawancara diatas diketahui kedua siswa tersebut mengalami kondisi tidak percaya diri dengan rencana karir yang akan diambil dikarenakan berbagai faktor penyebab. Hal ini menyebabkan siswa tersebut selalu memikirkan kembali rencana yang akan diambil, apakah menyesuaikan dengan kemampuan dirinya atau mengikuti arahan atau petunjuk dari orang lain. Kedua siswa tersebut pada akhirnya tidak dapat mengambil keputusan karir yang cepat

${ }^{25}$ Wawancara dengan DN pada tanggal 13 Januari 2020

${ }^{26}$ Dwi Purworahayu and Diana Rusmawati, "Hubungan Antara Kepercayaan Diri Dengan Kematangan Karir Pada Siswa Sma Negeri 1 Kemangkon Di Kabupaten Purbalingga," Empati 7, no. 2 (2018): 321-327.

${ }^{27}$ Wawancara dengan HR pada tanggal 13 Januari 2020

${ }^{28}$ Wawancara dengan AN pada tanggal 13 Januari 2020 
dan memerlukan pendampingan untuk memutuskan rencana karir yang tepat untuknya.

\section{Khawatir Tidak Terserap dalam Dunia Kerja}

Masalah yang terjadi saat ini, khususnya di Indonesia adalah jumlah lapangan kerja yang tidak sebanding dengan jumlah angkatan kerja. Jumlah angkatan kerja yang tidak terserap pada tahun 2016 sebanyak 7,03 juta orang. Jumlah angkatan kerja ini akan semakin bertambah seiring dengan banyaknya lulusan sekolah yang mulai mencari pekerjaan. ${ }^{29}$ Jumlah lapangan kerja yang ada masih sangat sedikit dikarenakan tidak banyak investor yang tertarik untuk membuka lapangan kerja di Indonesia. Hal ini menyebabkan setiap individu akan saling bersaing untuk mendapatkan pekerjaan sesuai dengan bidangnya. ${ }^{30}$ Persaingan ini tentu memerlukan kondisi psikologis yang kuat karena setiap individu berpotensi untuk tersingkir dari persaingan tersebut. Hal ini yang dirasakan oleh siswa SMKN 8 Penajam Paser Utara yang merasa khawatir tidak dapat masuk dunia kerja dikarenakan persaingan yang begitu ketat.

"Saya memilih untuk langsung bekerja, tapi saya khawatir, apakah dengan kemampuan yang saya miliki, mereka memilih saya atau orang lain yang kualitasnya lebih baik dari saya" ${ }^{31}$

"Saya pernah baca berita kalo sekarang ini banyak pengangguran dan yang terbanyak itu lulusan SMA/SMK, jadi saya khawatir apakah saya juga senasib dengan mereka",32

Dari hasil wawancara diatas, dapat diketahui bahwa kedua siswa tersebut mengalami kondisi tidak percaya diri dan khawatir tidak dapat terserap dunia kerja dikarenakan persaingan yang ketat untuk mendapatkan pekerjaan dan tidak semua siswa siap untuk menghadapi hal tersebut. Siswa memerlukan pendampingan untuk membantu meningkatkan kepercayaan diri dan mengurangi kekhawatirannya agar dapat menjalani rencana karirnya dengan baik dan tidak memperhatikan kondisi-kondisi di luar dirinya yang dapat berpengaruh negatif terhadap psikologis siswa tersebut.

Masalah efikasi diri rendah berkaitan dengan perencanaan karir siswa tersebut dapat disebabkan oleh berbagai faktor seperti keadaan fisiologis dan emosional yang tidak baik, seperti adanya kecemasan dan stress yang berlebihan menyebabkan individu tidak dapat mengendalikan dirinya dan berfokus untuk

${ }^{29}$ Shahnaz Syarifah Umary, and Imam Setyawan, "Kepercayaan Diri Dan Kematangan Karir Remaja Penerima Manfaat Di Balai Rehabilitasi Sosial Wira Adhi Karya Ungaran," Empati 5, no. 1 (2016): 28-32.

${ }^{30}$ Hendra Wijayanto and Samsul Ode, "Dinamika Permasalahan Ketenagakerjaan Dan Pengangguran Di Indonesia," Administratio: Jurnal Ilmiah Administrasi Publik dan Pembangunan 10, no. 1 (2019): 1-8.

${ }^{31}$ Wawancara dengan RF pada tanggal 13 Januari 2020

${ }^{32}$ Wawancara dengan EN pada tanggal 13 Januari 2020 
mengambil keputusan terkait perencanaan karir. ${ }^{33}$ Selain itu faktor lainnya adalah pengalaman orang lain (vicarious experiences) yang berada dalam kondisi sulit/gagal dalam merencanakan karir membuat siswa tersebut memiliki kekhawatiran akan mengalami masalah yang sama, sehingga berdampak secara psikis dan berakibat pada ketidakmampuan dalam menetapkan dan membuat keputusan karirnya. ${ }^{34}$ Masalah efikasi diri rendah yang dialami oleh para individu tersebut dapat ditinjau dari tiga dimensi efikasi diri menurut Bandura. Pertama adalah kesulitan yang dialami oleh individu tersebut dalam membuat perencanaan karir yang berada pada level tinggi sehingga tidak dapat mengambil keputusan yang cepat dan tepat dalam perencanaan karirnya. Kedua adalah Generalisasi, yaitu luas bidang pemahaman yang dimiliki oleh para individu tersebut yang masih terbatas sehingga memerlukan pendampingan untuk memperluas bidang pemahaman sehingga individu tersebut dapat merencanakan karirnya dengan baik. Ketiga adalah strength yaitu kekuatan akan kepercayaan diri individu yang rendah sehingga individu belum dapat membuat perencanaan karir dengan baik. $^{35}$

Masalah efikasi diri rendah yang dialami oleh para siswa perlu ditangani secara tepat agar para siswa dapat segera menetapkan keputusan karir yang akan diambil serta dapat mencapai kematangan karir siswa tersebut. Melalui efikasi diri yang baik, siswa dapat memiliki keyakinan akan kemampuannya dalam memilih dan menetapkan keputusan karir yang akan dipilih. Selain itu, melalui efikasi diri yang baik, siswa dapat mengatasi permasalahan yang dihadapi, ulet dalam berusaha, tanggap terhadap situasi dan kondisi yang terjadi sehingga mengarahkannya pada penyelesaian proses perkembangan karir yaitu menetapkan keputusan karir yang tepat dan mencapai kematangan karir di masa yang akan datang. ${ }^{36}$ Untuk mencapai efikasi diri yang baik pada siswa dalam menetapkan keputusan karirnya, Guru Bimbingan konseling (BK) menggunakan metode bimbingan kelompok sebagai media penyaluran informasi dan pemberian bantuan kepada siswa untuk membantunya dalam menetapkan keputusan karir yang akan dipilih. Menurut Guru BK, metode ini dipilih sesuai dengan kebutuhan siswa yang menghendaki adanya informasi yang mendalam mengenai karir serta upaya dalam membangun kepercayaan diri untuk memilih dan menetapkan keputusan karir yang akan dijalaninya nanti. Adapun dasar

${ }^{33}$ Vivik Shofiah and Raudatussalamah, "Self- Efficacy Dan Self- Regulation Sebagai Unsur Penting Dalam Pendidikan Karakter," Kutubkhanab: Jurnal Penelitian Sosial Keagamaan 17, no. 2 (2015): 214-229.

${ }^{34}$ Ibid.

${ }^{35}$ Ruth Imelda Kurniasari, Agoes Dariyo, and Rita Markus Idulfilastri, "Hubungan Antara Self-Efficacy Dengan Pengambilan Keputusan Karier Pada Mahasiswa Tingkat Akhir Fakultas Psikologi," Journal An-Nafs: Kajian Penelitian Psikologi 3, no. 1 (2018): 1-19.

${ }^{36}$ Jodi Setiobudi, "Pengaruh Efikasi Diri Terhadap Pengambilan Keputusan Karir Pada Siswa Kelas XII SMA Negeri 1 Kalasan,” E-Journal Bimbingan dan Konseling 1, no. 6 (2017): 98111. 
lainnya digunakannya layanan bimbingan kelompok ini didasarkan pada penelitian sebelumnya yang dilakukan oleh Metha Rezkyani Eka Putri, Fitria Kasih dan Rici Kardo yang menyatakan bahwa layanan bimbingan kelompok efektif dalam meningkatkan efikasi diri siswa dalam hal merencanakan karir. ${ }^{37}$ Adapun langkah-langkah yang dilakukan dalam layanan bimbingan kelompok ini adalah:

\section{Tahap Awal}

Dalam tahap awal ini Guru BK akan memperkenalkan diri dan juga memperkenalkan secara singkat kepada para siswa berkenaan dengan layanan bimbingan kelompok seperti definisi bimbingan kelompok, tujuan bimbingan kelompok, asas bimbingan kelompok serta aturan-aturan yang harus diikuti dalam kegiatan bimbingan kelompok. Untuk membangun hubungan yang lebih intim antar para siswa dan juga Guru BK, maka para siswa secara bergantian memperkenalkan diri masing-masing. Suasana yang dibangun dalam tahap ini adalah suasana yang santai dan tidak memberikan rasa tegang untuk anggota kelompok.

\section{Tahap Transisi}

Setelah mengadakan perkenalan dengan para siswa dan memperkenalkan secara singkat mengenai bimbingan kelompok, kemudian guru BK mempertanyakan kembali kesiapan dari para siswa untuk mengikuti bimbingan kelompok. Para siswa menyampaikan kesiapannya secara lisan dan juga tertulis yang dibuktikan dengan surat pernyataan yang ditandatangani oleh siswa tersebut. Selanjutnya guru BK akan menyampaikan pengantar dari karir dan disertai dengan penyampaian masalah yang dirasakan oleh para siswa tersebut berkenaaan dengan karir.

\section{Tahap Kegiatan}

Tahap ini merupakan tahap inti dari pelaksanaan bimbingan kelompok karena kegiatan bimbingan kelompok secara umum berada pada tahap ini. Setelah mendengar permasalahan dari para siswa, guru BK kemudian menyampaikan informasi mengenai cara memilih karir yang tepat sesuai dengan minat dan bakat siswa, informasi mengenai perkuliahan dan pekerjaan, menumbuhkan kepercayaan diri jika ada rencana yang telah dipilih, serta cara mengatasi hambatan apabila terjadi hal-hak yang tidak diinginkan, seperti dukungan yang minim dari keluarga. Para siswa kemudian memberikan tanggapan mengenai materi yang diberikan serta berdiskusi untuk menemukan solusi dari masalah yang mereka hadapi saat ini.

${ }^{37}$ Metha Rezkyani Eka Putri, Fitria Kasih, and Rici Kardo, "Efektivitas Bimbingan Kelompok Dalam Perencanaan Karir Peserta Didik Di Kelas XI Sman 2 Lubuk Basung,” Jurnal Konseling Indonesia 5, no. 2 (2018): 1-11. 


\section{Tahap Akhir}

Setelah penyampaian materi yang disertai dengan pemberian tanggapan serta berdiskusi, masalah yang ada pada diri siswa tersebut dapat ditemukan solusinya yang kemudian disepakati antara guru BK dan para siswa tersebut. Langkah berikutnya adalah menyimpulkan hasil pertemuan tersebut dan saling memberikan pesan dan kesan antara guru BK dan para siswa tersebut. Selain itu guru BK juga mengarahkan para siswa untuk kembali mengadakan layanan bimbingan kelompok apabila solusi yang telah disepakati tersebut kurang berhasil. Dari hasil layanan bimbingan kelompok yang dilakukan oleh guru BK, seluruh siswa yang sebelumnya mengalami efikasi diri rendah dan belum dapat menetapkan keputusan karir, mengalami perubahan menjadi pribadi yang lebih percaya diri dan telah menetapkan keputusan karir yang akan dijalaninya, yaitu sebanyak 5 orang siswa memilih untuk melanjutkan ke jenjang perkuliahan dan sebanyak 5 orang yang memilih untuk langsung bekerja sesuai dengan minatnya di sekolah.

Salah satu hambatan dalam upaya menetapkan pilihan karir yang akan diambil adalah kurangnya kepercayaan diri untuk memilih dan menetapkan jalur karir yang akan dijalani. Rendahnya kepercayaan diri tersebut dapat berdampak pada efikasi diri atau keyakinan individu bahwa yang bersangkutan dapat menetapkan keputusan karir yang dikehendaki serta mencapai kematangan karir. Efikasi diri sebagai sebuah dasar keyakinan pada individu menjadi modal yang penting dan diperlukan dalam menyusun perencanaan karir yang baik serta menjalani karir yang telah ditetapkan. Hal ini sejalan dengan penelitian yang dilakukan oleh Adhi Darmasaputro dan William Gunawan yang menyatakan bahwa sebanyak 70 persen siswa yang memiliki efikasi diri tinggi dapat menentukan keputusan karir yang akan diambilnya serta dapat mengikuti proses pengembangan karir, baik di perkuliahan maupun pekerjaan dengan baik, dan menjadikannya sebagai pribadi yang sukses. ${ }^{38}$ Dari hal tersebut, dapat menjadi poin penting bagi setiap siswa yang berada pada tingkat akhir di sekolah untuk memiliki efikasi diri yang tinggi agar siswa tersebut dapat mempersiapkan perencanaan karir yang baik, dan dapat menjalani pekerjaannya dengan baik.

Selain menjadi modal dasar untuk mencapai kematangan karir yang baik, efikasi diri juga berpengaruh terhadap tingkat kedudukan jabatan yang hendak dicapai individu dalam perjalanan karirnya. Individu yang memiliki efikasi diri yang tinggi dan disertai dengan kemampuan yang mumpuni dapat mencapai tingkat jabatan yang tinggi dalam sebuah instansi atau perusahaan. Begitu juga ketika individu tidak memiliki semangat yang kuat dalam bekerja dan tidak didukung dengan kompetensi yang baik, maka individu tersebut sulit untuk

38 Adhi Darmasaputro and William Gunawan, "Hubungan Efikasi Diri Pengambilan Keputusan Karier Dan Pengambilan Keputusan Karier Pada Siswa SMA," Jurnal Psikologi 14, no. 1 (2018): 1 . 
mencapai tingkat jabatan yang lebih tinggi. ${ }^{39}$ Dalam penelitian yang dilakukan oleh Susantoputri, Maria Kristina dan William Gunawan diketahui bahwa mayoritas individu usia muda pada rentang umur 30-35 tahun dapat mencapai puncak karir dengan dasar efikasi diri yang tinggi dan didukung dengan kemampuan manajerial dan kemampuan lain yang mendukungnya untuk berada pada tingkat jabatan yang lebih tinggi. Ketika individu telah berada pada posisi yang tinggi dalam struktur organisasi instansi/perusahaan, maka individu tersebut akan memperoleh penghargaan/reward berupa penghasilan dan tunjangan yang lebih tinggi dan sesuai dengan posisi dan beban kerja yang dimiliki individu tersebut. ${ }^{40}$ Dengan demikian, efikasi diri individu dalam hal karir, berpengaruh terhadap multiaspek seperti persiapan perencanaan karir, jabatan yang dijalani selamat berkarir serta penghasilan yang dapat diperoleh selama berkarir.

Untuk dapat mencapai efikasi diri yang baik dalam proses pengembangan karir, siswa dapat belajar dari pengalaman-pengalaman dari para alumni terdahulu yang telah berada pada kesuksesan dalam mengembangkan karir. Pengalaman-pengalaman tersebut dapat menjadi sebuah motivasi yang akan memacu semangat dari siswa untuk dapat menyiapkan perencanaan karir yang baik, memilih dan membuat keputusan karir yang baik serta menjalani karir yang telah dipilihnya dengan baik. ${ }^{41}$ Selain melalui pengalaman orang lain, efikasi diri dalam hal perencanaan karir dapat didorong melalui pendekatan persuasi yang dapat dilakukan oleh pihak guru BK atau konselor. Peran dari guru BK atau konselor dalam hal ini membantu siswa dalam menyiapkan perencanaan karir yang baik dan dapat membuat keputusan yang terbaik mengenai karir yang akan dijalani oleh siswa tersebut. Para guru BK dapat melakukan langkah persuasif untuk mengajak setiap siswa mempersiapkan perencanaan karir yang baik sejak dini sehingga siswa tidak mengalami kesulitan atau kebingungan dalam menyusun perencanaan karir dan menetapkan keputusan karir yang hendak dijalani. Peran dan langkah persuasif tersebut kemudian diimplementasikan dalam bentuk layanan bimbingan kelompok yang menjadi media dalam pemberian informasi dan bantuan kepada siswa dalam mengatasi kesulitan menentukan keputusan karir. ${ }^{42}$ Dalam kegiatan tersebut, siswa juga dapat

${ }^{39}$ Merida Sukma Praptiwi and Endang Sri Indrawati, "Efikasi Diri Dan Kecemasan Dalam Kompetisi Berwirausaha Pada Anggota Hipmi Universitas Diponegoro Semarang," Empati 4, no. 1 (2015): 106-110.

${ }^{40}$ Susantoputri, Maria Kristina, and William Gunawan, "Hubungan Antara Efikasi Diri

Karier Dengan Kematangan Karier Pada Remaja Di Daerah Kota Tangerang," Jurnal Psikologi UIN Sultan Syarif Kasim Riau 10, no. Juni (2014): 59-65.

41 Twi Tandar Atmaja, "Upaya Meningkatkan Perencanaan Karir Siswa Melalui Bimbingan Karir Dengan Penggunaan Media Modul," PSIKOPED AGOGLA Jurnal Bimbingan dan Konseling 3, no. 2 (2014): 57.

${ }^{42}$ Katharina Edeltrudis et al., "Model Bimbingan Kelompok Dengan Teknik Modeling Untuk Meningkatkan Kematangan Karir Siswa," Jurnal Bimbingan Konseling 6, no. 1 (2017): 68-76. 
berperan aktif untuk menyampaikan gagasan atau ide secara bebas dan terbuka untuk bersama-sama mencari alternatif penyelesaian masalah yang dihadapi oleh para siswa tersebut.

Kegiatan layanan bimbingan kelompok ini sebagai bagian dari alternatif pemecahan masalah yang dialami oleh siswa sekaligus memberikan kesempatan kepada siswa untuk memperoleh pengetahuan dan wawasan baru mengenai perencanaan karir dan cara menetapkan pilihan karir yang tepat. Kegiatan ini telah dipakai dalam beberapa penelitian dan berdampak positif terhadap perencanaan karir siswa, seperti dalam penelitian yang dilakukan oleh Mei Pritangguh yang menyatakan bahwa layanan bimbingan kelompok berdampak positif terhadap kesiapan siswa dalam menyusun perencanaan karir yang baik. ${ }^{43}$ Dalam penelitian lainnya yang dilakukan Suhas Caryono dan Endang Isnaeni dijelaskan bahwa layanan bimbingan kelompok efektif untuk membantu siswa dalam memilih jurusan perkuliahan maupun pekerjaan yang sesuai dengan minat dan bakat siswa. ${ }^{44}$ Lantas kemudian ketika layanan bimbingan kelompok ini diterapkan di SMKN 8 Penajam Paser Utara (PPU) hasilnya juga berdampak positif terhadap efikasi diri siswa dalam hal karir yaitu siswa dapat menentukan keputusan karir yang terbaik untuknya dan memiliki keyakinan dan kepercayaan diri yang kuat dapat menjalani proses pengembangan karir berikutnya dengan baik dan mencapai kematangan karir.

\section{Penutup}

Dari hasil penelitian yang dilakukan, diketahui terdapat beberapa gejala efikasi diri rendah pada siswa berkenaan dengan membuat keputusan karirnya, seperti kesulitan dalam menentukan keputusan karir, mengalami ketidakpercayaan diri terhadap karir yang telah dipilih, serta adanya kekhawatiran tidak dapat terserap dalam dunia kerja. Efikasi diri rendah pada siswa tersebut diakibatkan oleh kurangnya informasi dan dukungan untuk memilih dan menetapkan keputusan karir yang akan diambil. Permasalahan efikasi diri rendah tersebut diatasi melalui layanan bimbingan kelompk dengan beberapa tahap seperti tahap awal, tahap transisi, tahap kegiatan dan tahap akhir.

Dari penelitian yang telah dilakukan, peneliti memberikan beberapa rekomendasi/saran yang diantaranya adalah meminta kepada pihak guru di sekolah untuk lebih mensosialisasikan karir yang dapat dipilih oleh siswa, baik

${ }^{43}$ Mei Pritangguh, "Peningkatan Kemampuan Perencanaan Karier Melalui Bimbingan Kelompok Teknik Diskusi Pada Siswa SMAN 3 Kebumen Career Planning Ability Improvement Through Discussion Techniques Group Counseling," E-Journal Bimbingan dan Konseling 2, no. 6 (2017): 178-187.

${ }^{44}$ Endang Isnaeni Suhas Caryono, "Bimbingan Kelompok Siswa Kelas XII IPA Di SMAN 8 Purworejo ( Penelitian Tindakan Bimbingan Dan Konseling )," Jurnal Konseling Ilmiah 4, no. 2 (2014): 121-127. 
dalam melanjutkan pendidikan ataupun ketika bekerja. Rekomendasi berikutnya adalah meminta kepada pihak sekolah untuk turut serta mengajak para orang tua siswa untuk bersama-sama dapat membantu mengarahkan siswa dalam membuat keputusan karir sesuai dengan minat dan bakat siswa, serta meminta kepada pihak sekolah untuk dapat membuat sebuah kegiatan khusus yang didalamnya terdapat agenda untuk mengenal jurusan perkuliahan ataupun jenis pekerjaan dan skill yang diperlukan untuk dapat terserap dalam dunia kerja.

\section{Daftar Pustaka}

Alimudin, Imam A., Tatang Permana, and Sriyono Sriyono. "Studi Kesiapan Kerja Peserta Didik Smk Untuk Bekerja Di Industri Perbaikan Bodi Otomotif." Journal of Mechanical Engineering Education 5, no. 2 (2019): 191.

Ana, Aliqol, and Mungin Eddy Wibowo. "Bimbingan Kelompok Dengan Teknik Role Playing Untuk Meningkatkan Self-Efficacy Dan Harapan Hasil (Outcome Expectations) Karir Siswa." Jumal Bimbingan Konseling 6, no. 1 (2017): 49-53.

Anita, Rahmawaty. "Harmoni Dalam Keluarga Perempuan Karir: Upaya Mewujudkan Kesetaraan Dan Keadilan Gender Dalam Keluarga." Palastren 8, no. 1 (2015): 1-34.

Atmaja, Twi Tandar. "Upaya Meningkatkan Perencanaan Karir Siswa Melalui Bimbingan Karir Dengan Penggunaan Media Modul." PSIKOPEDAGOGIA Jurnal Bimbingan dan Konseling 3, no. 2 (2014): 57.

Claudia Charista, Lorensia, Yari Dwi Kurniangsih, and Tritjahyo Danny Soesilo. "Hubungan Efikasi Diri Dengan Kematangan Karir Siswa." Jurnal Penelitian dan Pengembangan Pendidikan 2, no. 1 (2018): 23-29.

Darmasaputro, Adhi, and William Gunawan. "Hubungan Efikasi Diri Pengambilan Keputusan Karier Dan Pengambilan Keputusan Karier Pada Siswa SMA." Jurnal Psikologi 14, no. 1 (2018): 1.

Edeltrudis, Katharina, Perada Korohama, Mungin Eddy Wibowo, and Imam Tadjri. "Model Bimbingan Kelompok Dengan Teknik Modeling Untuk Meningkatkan Kematangan Karir Siswa." Jumal Bimbingan Konseling 6, no. 1 (2017): 68-76.

Eka Putri, Metha Rezkyani, Fitria Kasih, and Rici Kardo. "Efektivitas Bimbingan Kelompok Dalam Perencanaan Karir Peserta Didik Di Kelas XI Sman 2 Lubuk Basung." Jurnal Konseling Indonesia 5, no. 2 (2018): 111.

Empati, Jurnal, Shahnaz Syarifah Umary, and Imam Setyawan. "Kepercayaan Diri Dan Kematangan Karir Remaja Penerima Manfaat Di Balai Rehabilitasi Sosial Wira Adhi Karya Ungaran.” Empati 5, no. 1 (2016): $28-32$.

Erlangga, Erwin. "Bimbingan Kelompok Meningkatkan Keterampilan Berkomunikasi Siswa.” Psympathic: Jurnal Ilmiah Psikologi 4, no. 1 (2017): 149-156. 
Frederica, Angela Gita. Hubungan Antara Efikasi Diri Dengan Pengambilan Keputusan Karir Pada Siswa/i Sekolah Menengah Kejuruan (Smk). Skripsi, 2020.

Herin, Mutiara, and Dian Ratna Sawitri. "Dukungan Orang Tua Dan Kematangan Karir Pada Siswa Smk Program Keahlian Tata Boga." Empati 6, no. 1 (2017): 301-306.

Isnain, Mauliddian, and Desi Nurwidawati. "Hubungan Antara Efikasi Diri Dengan Kematangan Karir Pada Siswa Kelas XI DI SMKN 1 Surabaya." Character: Jurnal Penelitian Psikologi 05, no. 02 (2018): 1.

Jendra, Arya Firmanu, and Sugiyo Sugiyo. "Pengaruh Efikasi Diri Terhadap Kecemasan Presentasi Siswa Kelas XI Di SMA Negeri 1 Wuryantoro." KONSELING EDUKASI "Journal of Guidance and Counseling" 4, no. 1 (2020): 138-159.

Khairun, Deasy Yunika, Melly Sri Sulastri, and Anne Hafina. "Layanan Bimbingan Karir Dalam Peningkatan Kematangan Eksplorasi Karir Siswa." Jurnal Penelitian Bimbingan Konseling 1, no. 1 (2016): 1-23.

Kurniasari, Ruth Imelda, Agoes Dariyo, and Rita Markus Idulfilastri. "Hubungan Antara Self-Efficacy Dengan Pengambilan Keputusan Karier Pada Mahasiswa Tingkat Akhir Fakultas Psikologi." Journal AnNafs: Kajian Penelitian Psikologi 3, no. 1 (2018): 1-19.

Laili Sulistyowati, Anis Nuril. "Layanan Bimbingan Kelompok Untuk Meningkatka Keterampilan Belajar Siswa." Edukasia: Jurnal Penelitian Pendidikan Islam 10, no. 2 (2015): 413-430.

Maulida, Nuzulia Intan. Pengarub Perencanaan Karir Dan Efikasi Diri Terbadap Kesiapan Kerja Peserta Didik Di SMK Se Kabupaten Tegal. Semarang: Universitas Negeri Semarang, 2017.

Nurmasari. "Peranan Penting Perencanaan Dan Pengembangan Karier." PUBLIKa.,Vol.1,No.2,Oktober,hal 268-281 (2015) 1, no. 2 (2015): 268281.

https://docs.google.com/viewerng/viewer?url=http://jurnal.uir.ac.id/i ndex.php/PUB/article/download/917/612.

Partino, H.R. "Kematangan Karir Siswa SMA." Psikologika : Jurnal Pemikiran dan Penelitian Psikologi 11, no. 21 (2006): 103-108.

Pasmawati, Hermi. "Urgensi Bimbingan Karier Di Perguruan Tinggi Untuk Membantu Kesiapan Mahasiwa Tahun Akhir Memasuki Dunia Kerja." Jurnal Ilmiah Syi'ar 18, no. 1 (2018): 1.

Permadi, Nofianti Eka. "Masalah-Masalah Yang Dihadapi Peserta Didik Dalam Perencanaan Karir Dan Implikasinya Terhadap Pelayanan Bimbingan Karir." Jurnal Penelitian Bimbingan dan Konseling 1 (2016): 134-145.

Permana, Hara, Farida Harahap, and Budi Astuti. "Hubungan Antara Efikasi Diri Dengan Kecemasan Dalam Menghadapi Ujian Pada Siswa Kelas Ix Di Mts Al Hikmah Brebes." Hisbab: Jurnal Bimbingan Konseling dan Dakwah Islam 13, no. 2 (2017): 51-68. 
Praptiwi, Merida Sukma, and Endang Sri Indrawati. "Efikasi Diri Dan Kecemasan Dalam Kompetisi Berwirausaha Pada Anggota Hipmi Universitas Diponegoro Semarang." Empati 4, no. 1 (2015): 106-110.

Pritangguh, Mei. "Peningkatan Kemampuan Perencanaan Karier Melalui Bimbingan Kelompok Teknik Diskusi Pada Siswa Smpn 3 Kebumen Career Planning Ability Improvement Through Discussion Techniques Group Counseling." E-Journal Bimbingan dan Konseling 2, no. 6 (2017): 178-187.

Purworahayu, Dwi, and Diana Rusmawati. "Hubungan Antara Kepercayaan Diri Dengan Kematangan Karir Pada Siswa Sma Negeri 1 Kemangkon Di Kabupaten Purbalingga." Empati 7, no. 2 (2018): 321-327.

Rusdyanto, Rizal. "Hubungan Antara Tingkat Self-Efficacy Dengan Tingkat

Kinerja Guru Di Sekolah Dasar Irada Gresik." Jurnal Psikosains 10, no. 1 (2015): 67-78.

Rustika, I Made. "Efikasi Diri: Tinjauan Teori Albert Bandura." Buletin Psikologi 20, no. 1 (2016): 18-25.

Setiobudi, Jodi. "Pengaruh Efikasi Diri Terhadap Pengambilan Keputusan Karir Pada Siswa Kelas XII SMA Negeri 1 Kalasan." E-Journal Bimbingan dan Konseling 1, no. 6 (2017): 98-111.

Shofiah, Vivik, and Raudatussalamah. "Self- Efficacy Dan Self- Regulation Sebagai Unsur Penting Dalam Pendidikan Karakter." Kutubkhanab: Jurnal Penelitian Sosial Keagamaan 17, no. 2 (2015): 214-229.

Suhas Caryono, Endang Isnaeni. "Bimbingan Kelompok Siswa Kelas XII IPA

Di SMAN 8 Purworejo (Penelitian Tindakan Bimbingan Dan Konseling

)." Jurnal Konseling Ilmiah 4, no. 2 (2014): 121-127.

Susantoputri, Maria Kristina, and William Gunawan. "Hubungan Antara Efikasi

Diri Karier Dengan Kematangan Karier Pada Remaja Di Daerah Kota

Tangerang." Jurnal Psikologi UIN Sultan Syarif Kasim Riau 10, no. Juni (2014): 59-65.

Wijayanto, Hendra, and Samsul Ode. "Dinamika Permasalahan Ketenagakerjaan Dan Pengangguran Di Indonesia." Administratio: Jurnal Ilmiah Administrasi Publik dan Pembangunan 10, no. 1 (2019): 1-8.

Yusanto, Yoki. "Ragam Pendekatan Penelitian Kualitatif." Journal of Scientific Communication (Jsc) 1, no. 1 (2020): 1-13.

Zamroni, Edris. "Urgensi Career Decision Making Skills Dalam Penentuan Arah Peminatan Peserta Didik." Jurnal Konseling Gusjigang 2, no. 2 (2016): 140_ 152.

Zenita Ratnaningsih, Ika, Erin Ratna Kustanti, Anggun Resdari Prasetyo, and Nailul Fauziah. "Kematangan Karier Siswa SMK Ditinjau Dari Jenis Kelamin Dan Jurusan.” Jurnal Humanitas 13, no. 2 (2016): 113-119. 